\title{
宇宙環境を想定した材料評価手法
}

\section{Evaluation Methods of Materials for Use under Space Environment}

宮崎 英治*

\author{
by
}

\section{Eiji MIYAZAKI*}

Key words: Space environment, Vacuum, Ultraviolet, Atomic oxygen, Outgassing, Contamination, Test

\section{1 はじめに}

人工衛星など宇宙機に用いられ，宇宙空間に曝される 材料は，過酷な宇宙環境に曝されることで，様々な影響 を受け, 変化 (時に損傷, 劣化) することが知られてい る。宇宙環境による材料損傷の程度の把握や, 而性向上 の対策の検証を行うため, 地上での宇宙環境模擬試験な どによる材料評価が行われている。本稿では，宇宙環境 による材料の変化と, 地上での評価例を紹介する。

\section{2 宇宙環境と材料への影響}

宇宙機とその構成材料が曝される宇宙環境は, 図 1 に 示すように複数の因子があり，過酷である，宇宙環境因 子には，真空，放射線，紫外線，温度サイクルなどがあ る。このほか, 高度数百 $\mathrm{km}$ の低軌道では, 原子状酸素 も重要な宇宙環境因子となる。宇宙環境に曝された材料 は，これら宇宙環境因子より様々な影響を受け，変化を 生じる，例えば，真空によるアウトガス，放射線による 脆化や変色, 紫外線による変色, 温度サイクルによる機 械的損傷（割れなど）, 原子状酸素によるエロージョン, といったものである。このような環境と, それによる変 化, その結果として生じる特性の変化により生じうる影 響を考慮し，宇宙機用材料は，それぞれが担っている機 能を十分に発揮し, 衛星が正常に動作するように性能を 維持するものを選択する必要がある。

本章では，宇宙環境として，真空，太陽光，原子状酸
素を取り上げ，それぞれが材料に及ぼす影響について概 説する.

\section{$\mathbf{2} \cdot \mathbf{1}$ 真空}

宇宙空間のうち, 地球近傍に着目すると, 地球表面か らの距離（高度）によって分布がある. 図 2 は, 大気圧 の高度分布を示したものである ${ }^{1)}$. 国際宇宙ステーショ ンや地球観測衛星が飛行する低高度地球周回軌道の高 度は, $400 \mathrm{~km} \sim 800 \mathrm{~km}$ である. 図 2 から, $10^{-5} \sim 10^{-7} \mathrm{~Pa}$ 程 度であることがわかる，真空下では，材料からアウトガ スが生じる. 発生したアウトガスが他の面, 特に光学機 器の光路上の面に付着すると, 污染（コンタミネーショ ン）し，観測性能低下の原因となる.

これまでに，コンタミネーションの影響が顕在化した と考えられている実例が報告されている ${ }^{2)}$.ここでは, 代表例として，「カッシーニ」での事例を示す.

「カッシーニ」は, NASA が 1997 年に打ち上げた土 星探査機である。図 3 は, カッシーニに搭載されたカメ ラでの観測画像である。画像下の数字は，「年/当該年の 通算日」を示している。すなわち，左が 2001 年の 87 日 目，右が同年の 150 日目のものである。両画像は，同一 の星を，同一の観測カメラで異なる時期に撮影したもの で，右の画像は，星の像の周辺に「にじみ」が生じてい ることが認められる。これは、コンタミネーションの影 響によるものであると，結論付けられている.

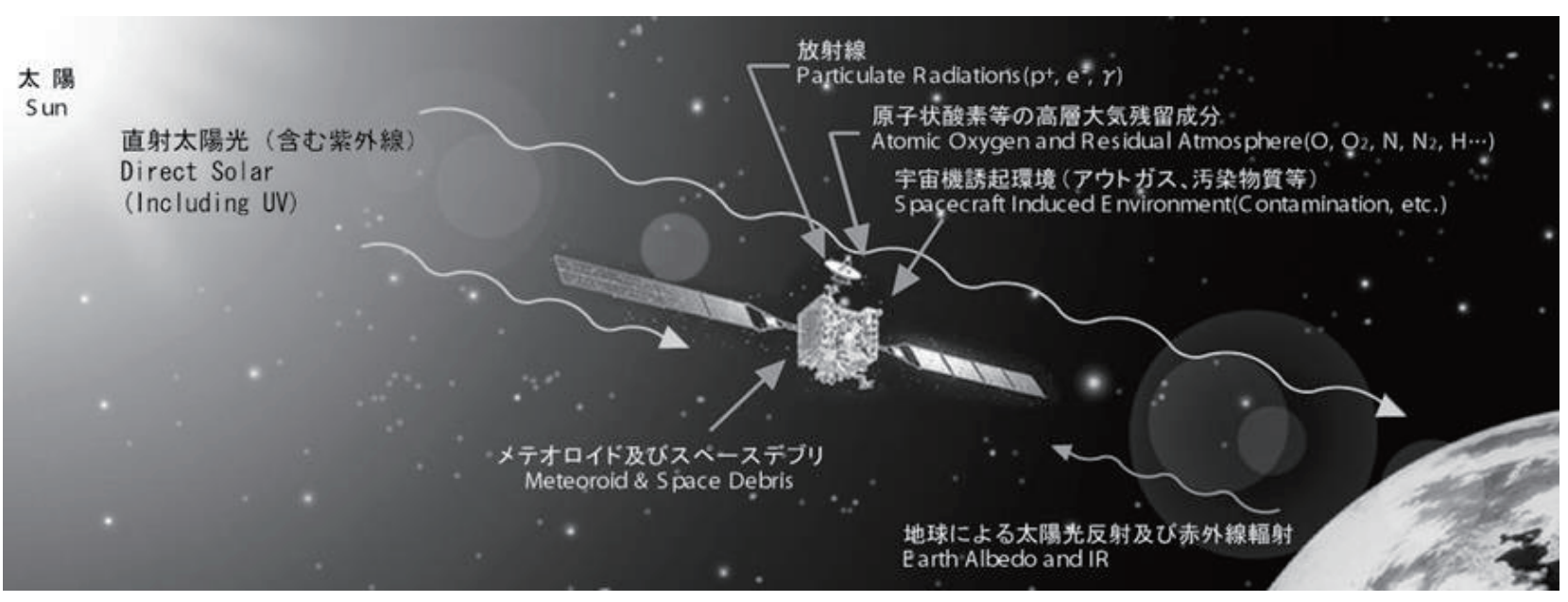

図 1 宇宙機が曝される宇宙環境

†原稿受理 平成28年11月16日 Received Nov. 16, 2016 o2017 The Society of Materials Science, Japan *国立研究開発法人宇宙航空研究開発機構, テ305-8505つくば市千現, Japan Aerospace Exploration Agency, Sengen, Tsukuba, 305-8505 


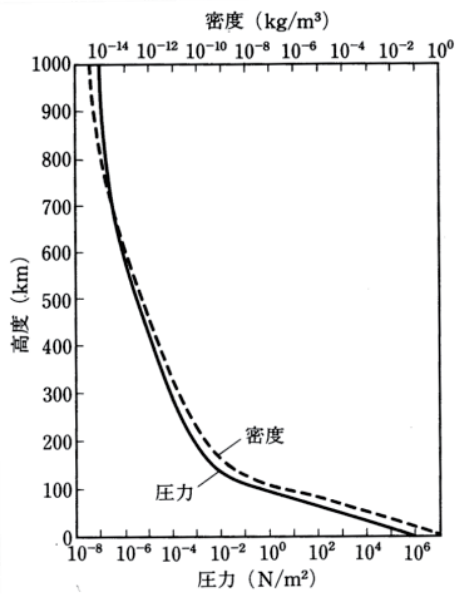

図 2 宇宙における圧力と密度の高度分布 ${ }^{1)}$

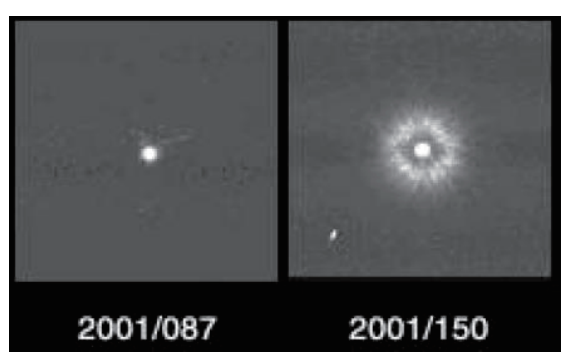

図 3 「カッシーニ」光学観測画像の品質低下例 2)

\section{$2 \cdot 2$ 太陽光}

宇宙空間において太陽光は，大気層を通過していない ため，強度が強い上，地球表面には届かない上うな短波 長の紫外線が到達する. 大気圈外の太陽光の分光強度を 図 43)に示寸.

高強度の太陽光が入射するため, 宇宙機の日照部分は 高温になる。一方, 日陰部分, あるいは太陽光が入射し ない夜には，低温になる。低高度地球周回軌道の宇宙機 は，およそ 90 分で 1 周回するため, 日照〜日陰を繰り 返し，その結果，高温～低温を繰り返すことになる，図 5 は，小型実証衛星 4 型（SDS-4）に搭載した「THERME を用いた熱制御材実証実験」（IST）で取得した軌道上デ 一夕の例である ${ }^{4)}$ 。この図からわかるとおり， $+60^{\circ} \mathrm{C} \sim$ $-40^{\circ} \mathrm{C}$ の幅で変動している.このため, 厳しい温度サイク ルに見舞われる，異種材料の結合部などは，熱膨張率の 差による繰り返し応力の発生と疲労に留意する必要が ある。

さらに，紫外線の影響も考慮しなければならない，特 に，有機材料などは紫外線入射によって化学結合が切断 するなどの影響を受ける。その結果，特性が変化してし まう。図 6 は，図 5 と同じくSDS-4/IST の事例で，搭載 材料の太陽光吸収率の長期的変化の観測結果である. 数 值が上昇しているのは，紫外線の影響で色が褐色に変化 し，太陽光を吸収しやすくなったことを示している。太 陽光吸収率が高くなると，図 5 の日照時高温の到達温度 が，より高くなる結果に至る。

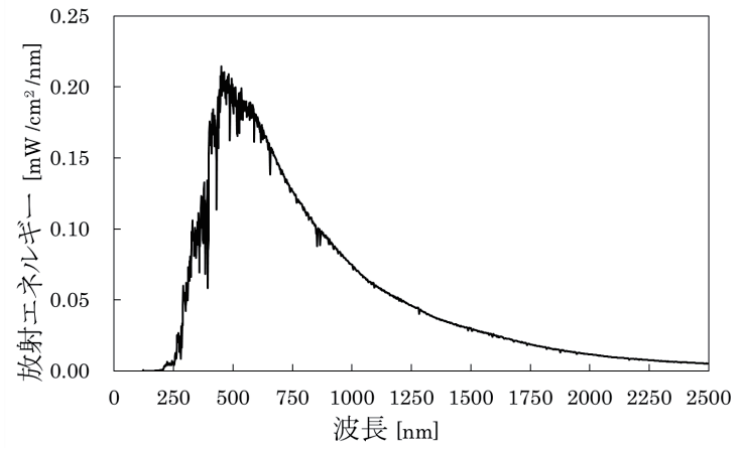

図 4 大気圏外（Air Mass Zero）の太陽光分光強度 ${ }^{3)}$

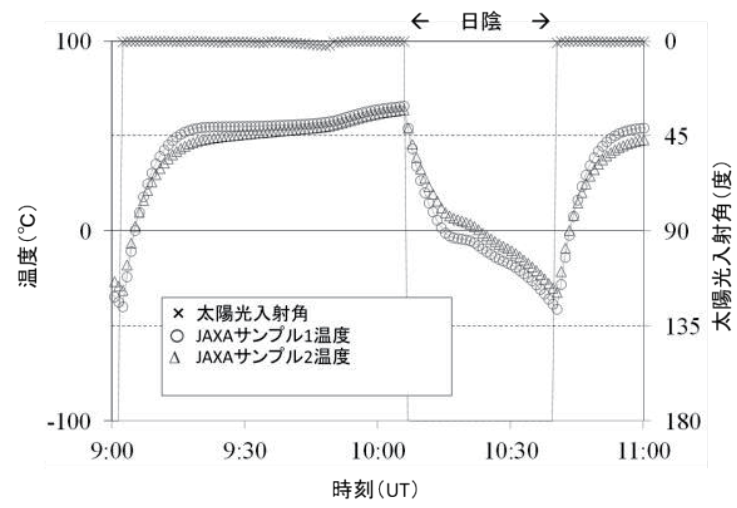

図 5 SDS-4 搭載 IST の飛行中温度データ 4)

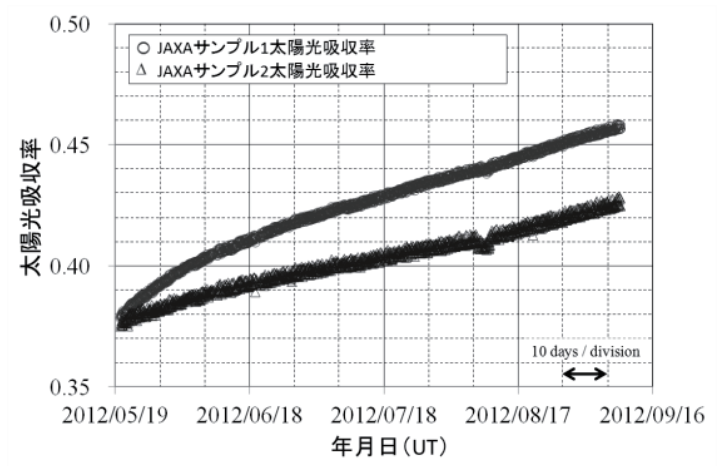

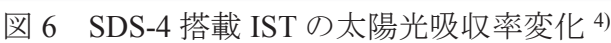

\section{$2 \cdot 3$ 原子状酸素}

宇宙空間の雾囲気圧力は, 前述のように, 図 2 に示寸 ような高度分布がある。図 2 は全圧を示しており, これ に対して成分毎に分割して密度の高度分布を示したも のが，図 75)である。高度 $200 \mathrm{~km}$ 付近より低いと $\mathrm{N}_{2}$ が支 配的であるが，高くなると O，すなわち原子状酸素が支 配的になる。原子状酸素は, 地球大気に含まれる酸素 $\left(\mathrm{O}_{2}\right)$ が太陽光の紫外線によって解離し，存在している. その中を宇宙機が $8 \mathrm{~km} / \mathrm{s}$ で飛行するため, 宇宙機表面と 原子状酸素が高いエネルギー（およそ $5 \mathrm{eV} ）$ で衝突し， その結果，有機材料などでエロージョンが生じることが ある。

図 8 に示す写真は, 国際宇宙ステーション (International Space Station: ISS）で発生した，熱制御フィルムの損傷 


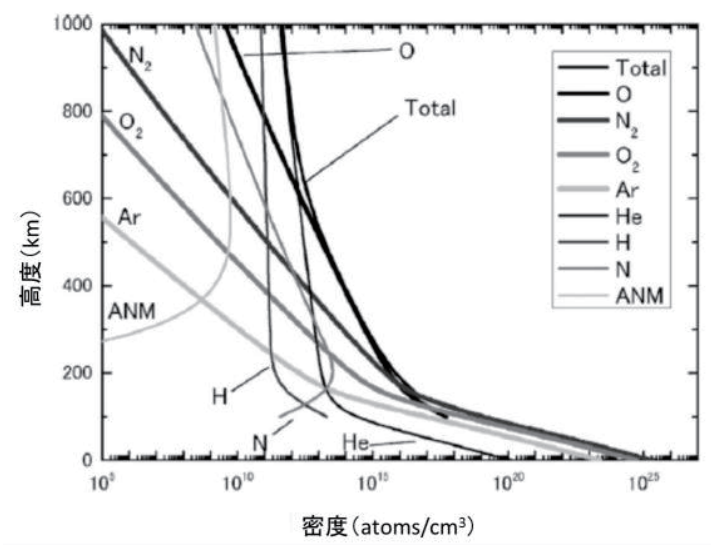

図 7 大気組成の高度分布 ${ }^{5)}$
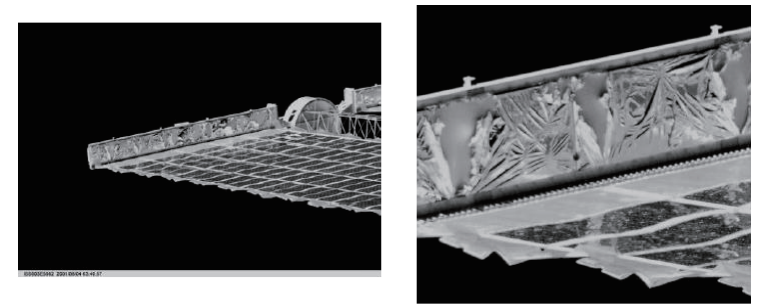

図 8 ISS での熱制御フィルム損傷例 6)

例である ${ }^{6)}$.このフィルムは，元々ポリイミドフィルム の両面にアルミニウムを蒸着したものである. ポリイミ ドは，高い耐熱性を有するなど高性能材料の一つである ので，宇宙機用途として幅広く使われているが，原子状 酸素との衝突によってエロージョンされる物質として もよく知られている.アルミニウム蒸着膜は原子状酸素 からの保護膜として機能することが期待されていたも のの， 1 年程度の期間で図 8 のように, ポリイミド層が 失われ, アルミニウム蒸着膜がめくれている様相を呈し てしまったのである. 原因は, アルミニウム蒸着膜の微 小な欠陥を通って原子状酸素がポリイミド層に到達し, それによってポリイミド層のエロージョンが生じた，と 推定されている.

\section{3 材料評価}

前章で述べたような宇宙環境と材料影響・損傷を評価 する手法があり，宇宙機開発においてその評価結果が適 用されている、本章では, 筆者が所属する部門で実施し ている評価試験の概要を紹介する.

\section{$3 \cdot 1$ アウトガス・アウトガスレート測定試験}

使用する材料は重大なコンタミネーション源となり 得るため, アウトガスを放出しにくい材料を選定しなけ ればならない。この選定，すなわちスクリーニングのた めの試験を実施している。これは「アウトガス測定試験」 と呼ばれる. 米国試験規格 ASTM E 5957)や欧州の宇宙機 試験規格 ECSS-Q-ST-70-028)に規定されており，JAXA で はASTM E 595 に則った試験を行う装置（図 9）を有し
ている.

使用する材料がコンタミネーション源としてどのよ うな長期的特性を持つのか, 把握するための試験を実施 している。これは「アウトガスレート測定試験」と呼ば れ, 米国試験規格 ASTM E 15599)や欧州の宇宙機試験規 格 ECSS-Q-TM-70-52A $\mathrm{A}^{10)}$ に規定されている.JAXA では 図 10 の測定装置を整備して, 試験を行っている.

アウトガスレート測定試験は，材料サンプルを真空下 で加熱し, アウトガスの放出／付着特性を連続的, かつ 定量的に測定する試験である. 図 11 に装置の概念図を 示す．材料サンプルは加熱セルに収納し, 試験温度（設 定可能範囲：室温～ $398 \mathrm{~K}\left(125^{\circ} \mathrm{C}\right)$ ） に保持寸る. 加熱セ ルには，材料からのアウトガスがセル外に放出される才 リフィスが 1 箇所あり，そのオリフィスの対面に温度制 御可能な QCM が 4 個設置されている. 各 QCM の温度 は独立して制御されており， $80 \mathrm{~K}\left(-193^{\circ} \mathrm{C}\right) \sim 398 \mathrm{~K}\left(125^{\circ} \mathrm{C}\right)$ の任意温度に設定できる. 加熱セルから放出されたアウ トガスは，4個の QCM に入射し，QCM 温度に応じた付 着量の時間変化が計測される. なお，加熱セルのオリフ イスから QCM に至る経路の周囲は, 液化窒素で泠却し たシュラウドで囲まれており，これによって壁面からの ガス放出及びアウトガスの反射の影響は生じない構造 となっている.

\section{$3 \cdot 2$ 紫外線照射試験}

JAXA 筑波宇宙センターには, 図 4 のスペクトルを模 擬した紫外線を照射する装置「紫外線照射チャンバ」(図 12）がある. $5 \mathrm{~kW}$ キセノンショートアークランプを光 源とし, 真空チャンバ内のサンプルホルダ上 $150 \mathrm{~mm} \times$ $150 \mathrm{~mm}$ の範囲に照射できる.この照射装置を用いた評価 例を図 13 に示す. 50[ESD] (ESD : Equivalent Solar Days, 照射量の単位で, 1 [solar]の強度で 1 日入射したときの照 射量が 1[ESD]）の紫外線を照射したポリエーテルスルフ オン（PES）フィルム（裏面アルミニウム蒸着品）の外 観を示す. 図 13(b)のサンプル中央部（紫外線が照射さ れた領域）の色調が変化（褐色化）している.このサン プルの太陽光吸収率を測定すると, 照射前 0.15 に対し, 照射後 0.48 と大きく増加した. 従って, 50[ESD]の紫外 線が入射し, 変色した後では, 太陽光による入熱量が 3 倍程度増加することになる。一方, 垂直赤外放射率は, 照射前 0.90 , 照射後 0.91 とほとんど変化していない。こ のような傾向は一般的であり, 紫外線を照射すると変色 して太陽光吸収率は増加する一方で, 垂直赤外放射率は 変化しない, という結果を示す材料が多い。

\section{$3 \cdot 3$ 原子状酸素照射試験}

JAXA 筑波宇宙センターには, さらに, 宇宙用材料評 価のためのユニークな設備がある。「真空複合環境試験 設備」（図 14）といい, 原子状酸素, 電子線, 真空紫外 線の 3 種類のビームを単独, または任意の組み合わせで 照射することができる ${ }^{11)}$. サンプルホルダは $170 \mathrm{~mm} \times$ 


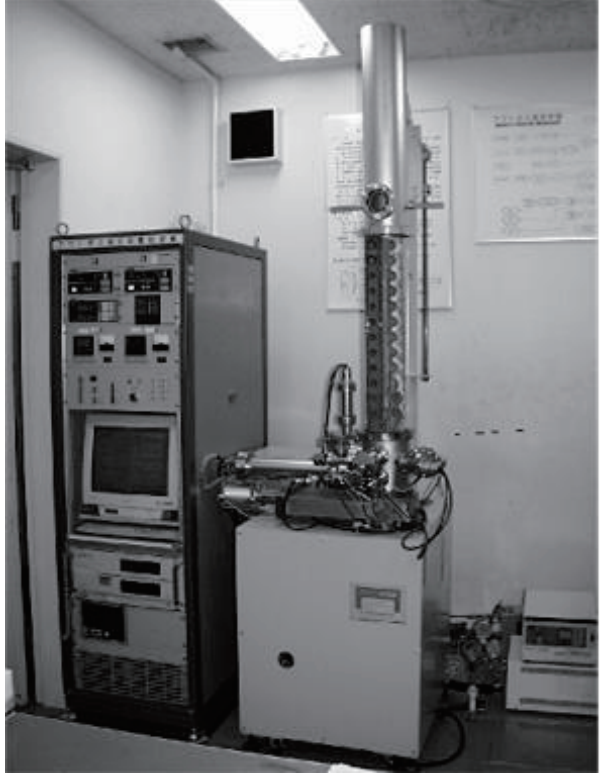

図 9 アウトガス測定装置

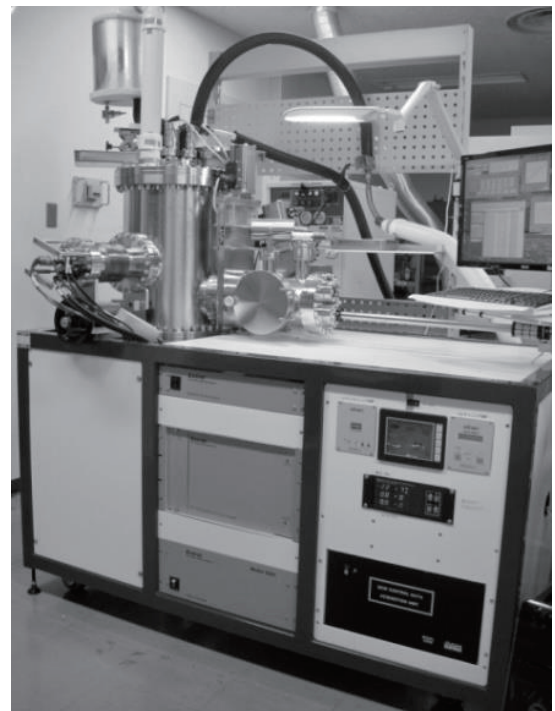

図 10 アウトガスレート測定装置

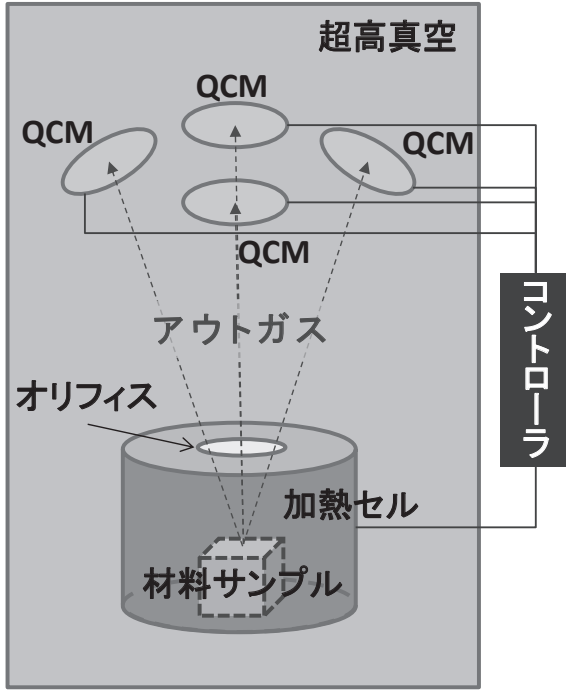

図 11 アウトガスレート測定装置の概念図

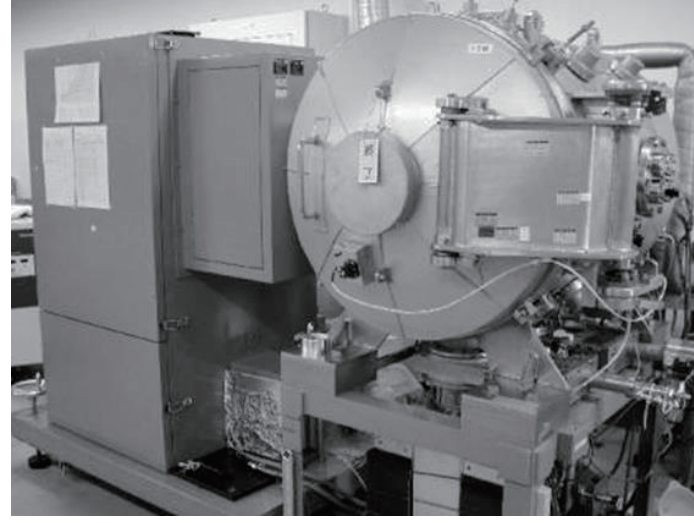

図 12 紫外線照射チャンバ

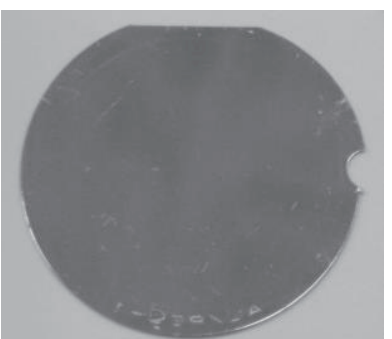

(a)照射前

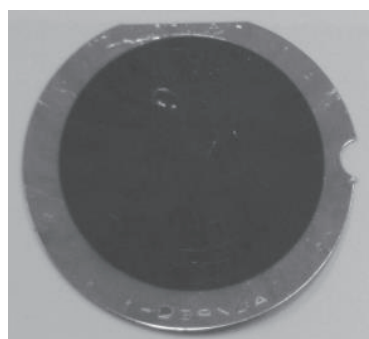

(b)50ESD 照射後
図 13 紫外線照射前後の PES フィルム

$200 \mathrm{~mm}$ の範囲に, $25 \mathrm{~mm} \phi \times 18$ 枚のサンプルを固定する スロットがある。この設備の原子状酸素照射装置は，レ ーザデトネーション法によるものである，真空チャン バ内のノズルに酸素ガスを導入し, 同期して $\mathrm{CO}_{2}$ パルス レーザ光（波長 $10.6 \mu \mathrm{m}$ ）を放射させ，ノズル内に集光 することで，人工衛星の飛行速度 $(8 \mathrm{~km} / \mathrm{s}$ 程度）と同等 の原子状酸素ビームを生成し, サンプルホルダに向けて 照射する方式である。

原子状酸素を照射したサンプルの評価例を示す ${ }^{12)}$. 図 15 は，原子状酸素を照射したUpilex $®-S$ フィルムの表面 SEM 像である。Upilex $囚-S$ に限らず，有機材料に原子状 酸素を照射するとエロージョンが生じ，同様の $\mu \mathrm{m}$ オー ダの凹凸を形成する。これらは，マクロには「すりガラ ス」様の表面を呈し，白濁して見える.

定量的には，質量減少を計測し，原子状酸素の衝突量 に対する質量減少の感度指標となる「反応効率」を評価 する。リファレンスとなるのはポリイミドフィルム Kapton ${ }^{\circledR} \mathrm{H}$ で，その反応効率は $3.0 \times 10^{-24}\left[\mathrm{~cm}^{3} /\right.$ atom $]$ であ る.

\section{4 これから}

前章までに述べた内容は，宇宙機開発において標準的 なものとして，現在実施しているものである．さまざま な経験を元に，知見を集約して，一つの形になったもの であり，宇宙開発の礎となる技術であることは間違いな い.

一方で，今後の宇宙開発分野においては，大きな変化 が訪れることは間違いない。諸外国の宇宙活動の様子に 


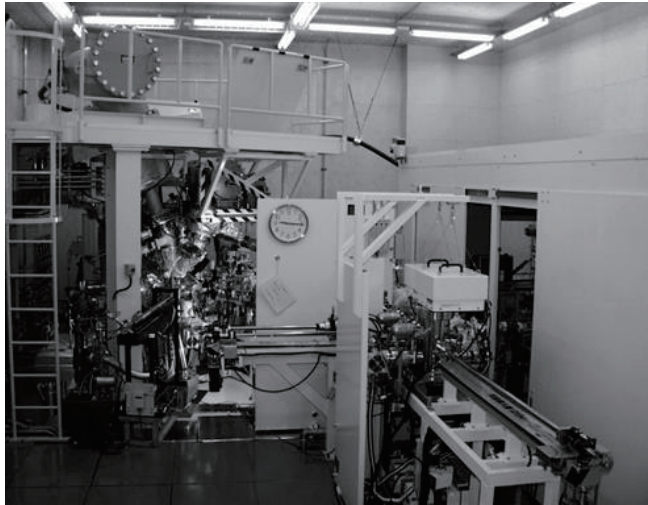

図 14 真空複合環境試験設備

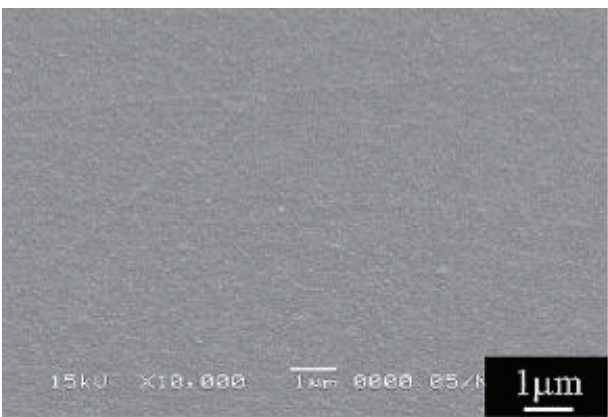

(a)照射前

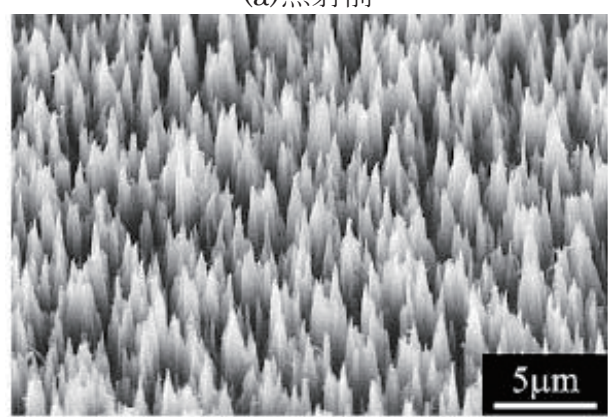

(b) $8.5 \times 10^{20}\left[\right.$ atoms $\left./ \mathrm{cm}^{2}\right]$ 照射後

図 15 原子状酸素照射前後のUpilex ${ }^{\circledR}-\mathrm{S}$ フィルムの表面 SEM 像 ${ }^{12)}$

目を向けてみると，民間部門の参入などによる劇的な変 化の波が既に到来している。このような流れの中で，こ れまでとは異なる考え方や手法を取り入れていかなけ ればならないであろう。従来, 宇宙機は数量が出ないた め, 常に一品物として扱われ，その上，あるいは，その 結果, 高価になってしまっている。その結果, 厳重な品 質管理や膨大な試験検証を必須として製作されてきた, という状況にある，前述のように，大きな変化が起き始 めていると考えると，より一般的な産業製品として製作 された宇宙機の実現が必要であると考える.

現在は, 特殊な分野として認識されている宇宙機開発 を，より一般的なものに近づけ，産業としての裙野を広 げることが急務であると感じている，日本の宇宙産業が，
世界から取り残されないよう, 今から, 次の手を打ち出 していかなければならないと思う。

\section{5 まとめ}

本稿では，宇宙機用材料が，いかなる環境に曝され， どのような影響を受けるのか，概説した。その観点で， 現在，JAXA 筑波宇宙センターにおいて実施している， アウトガス評価, 紫外線照射, 原子状酸素照射を代表例 として取り上げ，その手法と評価の実例を紹介した。 昨今の宇宙開発分野を取り巻く状況に鑑みると, 将来 に向けた活動を始めなければならないと, 筆者は強く感 じている. 本稿が，宇宙開発と宇宙機用材料分野に興味 を持っていただくきっかけとなれば幸甚である.

\section{参考文献}

1) Materials Science Society of Japan (ed.), "Materials for space technology," Shokabo, p.22 (1991).

2) V. R. Haemmerle and J. H. Gerhard, "Cassini Camera Contamination Anomaly: Experiences and Lessons Learned," AIAA paper, AIAA-2006-5834 (2006).

3) ASTM Standard E490-00a (2006), "Standard Solar Constant and Zero Air Mass Solar Spectral Irradiance Tables," ASTM International, West Conshohocken, PA (2006).

4) E. Miyazaki, Y. Kimoto, Y. Nakamura, K. Fujihira, S. Remaury, S. d'Escrivan and P. Nabarra, "Preliminary results of In-flight experiment of space materials using THERME (IST) on Small Demonstration Satellite-4 (SDS-4)," Proceedings of 56th Space Sciences and Technology Conference, 1L07 (2012).

5) Y. Kimoto, E. Miyazaki, J. Ishizawa and H. Shimamura, "Atomic Oxygen Effects on Space Materials in Low Earth Orbit and Its Ground Evaluation,” J. Vac. Soc. Jpn., Vol. 52, No. 9, pp. 475-483 (2009).

6) B. A. Banks, A. Snyder, S. K. Miller and R. Demko, "Issues and Consequences of Atomic Oxygen Undercutting of Protected Polymers in Low Earth Orbit," NASA/TM-2002-211577 (2002).

7) ASTM E595-93(1999), Standard Test Method for Total Mass Loss and Collected Volatile Condensable Materials from Outgassing in a Vacuum Environment, ASTM International, West Conshohocken, PA (1999).

8) European Space Agency, "Thermal vacuum outgassing test for the screening of space materials," ECSS-Q-ST-70-02 (2008).

9) ASTM E1559-09, Standard Test Method for Contamination Outgassing Characteristics of Spacecraft Materials, ASTM International, West Conshohocken, PA (2009).

10) ESA-ESTEC Requirement and Standards Division, "Space product assurance Kinetic outgassing of materials 
for space," ECSS-Q-TM-70-52A (2011).

11) H. Shimamura, S. Baba, E. Miyazaki, "Handbook of the Combined Space Effects Test Facility," JAXA research and development memorandum, JAXA-RM-10-013 (2011).

12) H. Shimamura, T. Nakamura, "Mechanical Properties Degradation of Polyimide Films Irradiated by Atomic Oxygen," Polymer Degradation and Stability, Vol. 94, pp. 1389-1396 (2009). 